\title{
Recovering Plant Data for Guinea-Bissau: Implications for Biodiversity Knowledge of West Africa
}

\author{
Maria M. Romeiras ${ }^{1,2, *} \mathbb{E}$, Maria Cristina Duarte ${ }^{2} \mathbb{D}$, Javier Francisco-Ortega ${ }^{3,4}$, \\ Luís Catarino ${ }^{2}$ (D) and Philip Havik 5 \\ 1 Linking Landscape, Environment, Agriculture and Food (LEAF), Instituto Superior de Agronomia, \\ Universidade de Lisboa, 1349-017 Lisbon, Portugal \\ 2 Centre for Ecology, Evolution and Environmental Changes (cE3c), Faculdade de Ciências, \\ Universidade de Lisboa, 1749-016 Lisbon, Portugal; mcduarte@fc.ul.pt (M.C.D.); lmcatarino@fc.ul.pt (L.C.) \\ 3 International Center for Tropical Botany, Department of Biological Sciences, Florida International University, \\ Miami, FL 33199, USA; ortegaj@fiu.edu \\ 4 Kushlan Tropical Science Institute, Fairchild Tropical Botanic Garden, Coral Gables, FL 33156, USA \\ 5 Centre for Global Health and Tropical Medicine, Instituto de Higiene e Medicina Tropical, \\ Universidade NOVA de Lisboa, 1349-006 Lisbon, Portugal; philip.havik@ihmt.unl.pt \\ * Correspondence: mmromeiras@isa.ulisboa.pt; Tel.: +351-21-365-3100
}

Received: 10 September 2018; Accepted: 1 October 2018; Published: 6 October 2018

check for updates

\begin{abstract}
The rich plant diversity that characterizes the West African Region and the inherent knowledge of their flora and vegetation has been the backbone of scientific explorations during the past centuries. The evolution of botanical knowledge on Guinea-Bissau, throughout the 16th and 20th centuries is reviewed. We present and discuss floristic data collected by scientific expeditions between the mid-1700s to 1974, when the Portuguese colonial period ended. Expeditions undertaken by French naturalists provided some of the earliest plant collections. A list of herbarium specimens collected by the French naturalist Jardin, in the Bijagós Islands in ca. 1847-1858 is presented here for the first time, while in the late 1800s some Portuguese naturalists also explored Guinea-Bissau. During the colonial period (1915-1974), Gomes e Sousa published the first comprehensive study of the territory's flora while Espírito Santo assembled the largest plant collection. Our review applies a multi-disciplinary perspective to fill important lacuna regarding biodiversity knowledge of this under-researched West African country. It constitutes the first study tracing the long term evolution of knowledge on Guinea Bissau's plant diversity, which provides the basis for understanding trends and research priorities, in particular in conservation and botanical fields.
\end{abstract}

Keywords: plant diversity; botanical history; West Africa; scientific collections; naturalists; African Flora

\section{Introduction}

The West African country of Guinea-Bissau shares common frontiers with Senegal and the Republic of Guinea, while bordering the Atlantic Ocean (Figure 1A). It is characterized by low-lying littoral areas of mangroves, gradually shifting in an easterly direction to a transitional zone covered with palm forests and woodland (Figure 1B), extending to a slightly elevated savannah plain and the outliers of the Futa Djallon Massif (Republic of Guinea), sloping upwards to a maximum elevation of $300 \mathrm{~m}$ [1]. The Bijagós Islands off the coast, covered with mangroves, palm groves and dry forested areas (Figure 1C), form a continuation of the coastal plateau which is dissected by a number of rivers such as the Cacheu, Mansoa, Geba and Corubal, and the Rio Grande de Buba (Figure 1A). 
Guinea-Bissau's vascular flora comprises ca. 1507 species, of which 1459 are native. The native vascular plants are classified into 157 plant families and 697 genera, namely: 22 species belonging to 14 families are Pteridophyte sensu lato; and among the angiosperms: 396 species belonging to 33 families are Monocots; and 1041 species, belonging to 107 families are Eudicots [2]. Despite the great number of plant species native to Guinea-Bissau, the uniformity of ecological conditions and the size of the territory have not favored endemic species, and only Pandanus guineabissauensis Huynh and Ammannia santoi (A. Fern. \& Diniz) S.A. Graham \& Gandhi are in-country endemic. This country boasts a great cultural diversity that has resulted in significant ethnobotanical traditions [3].

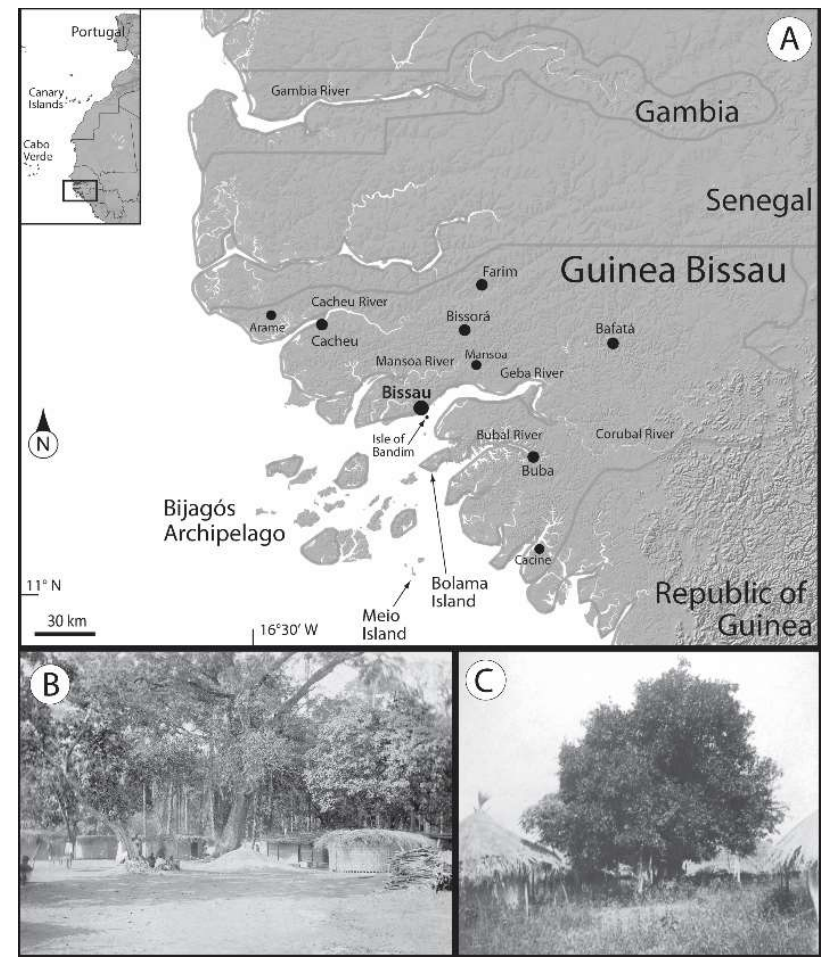

Figure 1. (A) West Africa with details of the modern-day boundaries of Guinea-Bissau, which were only established in 1886, following the treaty between France and Portugal. Localities indicated on the map were the focus of the first botanical expeditions, which mainly centered on insular and coastal areas. (B) Bafatá region: camp in Irancunda (Canadú); (C) Bijagós archipelago (Agô Grande). Copyright, Instituto de Investigação Científica Tropical (IICT/Universidade de Lisboa), Portugal.

The aim of this paper is to review the accumulation of botanical knowledge on West Africa by addressing historical aspects of early plant records and studies made in the former Portuguese continental colonies of this region and particularly in what was known as Portuguese Guinea, today the country of Guinea-Bissau. We document present and past botanical knowledge on the region by means of a critical survey of herbarium collections and historical literature on the territory's flora. Important in this contribution is the gradual shift from native to introduced crops, particularly from the early 1800s, mainly for commercial purposes. Three key periods regarding the evolution of knowledge on Guinea-Bissau's flora and vegetation are identified here, namely: (i) early botanical records, with details on travel accounts and reports of plants and local vegetation between the 15th and 17th centuries; (ii) botanical explorations from the late 18th to the last quarter of the 19th century, with details on French and Portuguese naturalists' collections against the background of agricultural change; (iii) state sponsored botanical missions and studies from the early 1900s to the end of the colonial period (1974). Our contribution attempts to demonstrate to what extent a longitudinal perspective upon botanical exploration can contribute to filling important gaps in the knowledge of the flora and vegetation of a hitherto neglected West African region. 


\section{Evolution of Knowledge on Guinea-Bissau's Flora and Vegetation}

\subsection{Early Records of Botanical Knowledge}

The earliest records on the geographical area that currently includes Guinea-Bissau date back to the mid-15th century, when travelers, traders and chroniclers began to provide-as yet patchy-information on the climate, topography, flora and fauna, and human settlements [4-8]. One of the earliest accounts of West Africa is provided by Alvise Cadamosto in 1455-1456 [5] while visiting the Senegambian area. In his report Cadamosto referred to some main crops and staple foods, namely two kinds of grains, "large and small" (probably Sorghum bicolor (L.) Moench and Pennisetum glaucum (L.) R.Br., respectively), two types of beans and the oil palm tree (Elaeis guineensis Jacq.) from which the locals obtained both oil from the seeds and wine from the sap [5]. At the turn of the 15th century (1506-1507), the chronicler Valentim Fernandes confirmed the abundance of sorghum (Sorghum bicolor (L.) Moench), millet (Pennisetum glaucum (L.) R.Br.) and yams (Dioscorea spp.) along the basins of the Gambia and Geba rivers [8]. In addition, he reported the presence of certain tree species such as the oil palm tree, the shea tree or carite (Vitellaria paradoxa C.F.Gaertn.), and the Guinea plum (Parinari excelsa Sabine) (Figure 2A).

The period from the 1500s to the end of 1700s was characterized by the trans-Atlantic slave and commodity trade. As West Africa became a much coveted source of slave exports, the northeastern Atlantic archipelagos of Macaronesia and above all the Cabo Verde Islands were to evolve into hubs for trans-Atlantic trade routes [9]. From the mid-1500s, the coastal area of the Rivers of Guinea (including current day Guinea-Bissau) were governed from the Cabo Verde archipelago by Portuguese officials. In the process, the islands were to become the subject of numerous travel descriptions reporting on the local flora and on the introduction of new crops such as sugar cane, maize and cotton $[10,11]$.

In the course of the 16th and 17th century as traders advanced deeper into West Africa by means of an elaborate network of rivers and sea inlets, their observations contain valuable insights into local vegetation, settlement, and cultivation patterns [12]. Besides abundant references in 16th century travel accounts to rice (Oryza spp.) and millet, the regions' principal crops, such as the kola tree (Cola nitida (Vent.) Schott \& Endl.) and indigo (Indigofera tinctoria L.) are also mentioned for the first time. Among the native trees, African rosewood (Pterocarpus erinaceus Poir.) (Figure 2B), the ordeal tree (Erythrophleum suaveolens (Guill. \& Perr.) Brenan) whose bark was used to extract poison, a much appreciated, pear shaped yellow fruit (probably Gardenia ternifolia Schum. \& Thonn), and the locust bean tree (Parkia biglobosa (Jacq.) R.Br. ex G.Don) (Figure 2C), stood out and were mentioned by the Portuguese explorer André Álvares d'Almada, 1594 [4]. Other contemporary travel accounts also referred a number of plants whose fruit and seeds were and are still widely used in the local diet or for phytotherapeutic preparations [7]. Donelha's texts provided the first inventory of plant species from this area [12]. These include Guinea pepper or black malagueta (Xylopia aethiopica (Dunal) A.Rich.), the African fan palm (Borassus aethiopum Mart.), the copal tree (Guibourtia copallifera Benn.), strophanthus (Strophanthus hispidus DC. and S. sarmentosus DC.), and false yam (Icacina oliviformis (Poir.) J.Raynal). During the 17th century, travel accounts such as those by Lemos Coelho in 1669 and 1684 [6] also mentioned a number of tree species common to Senegambia and West Africa, including the baobab tree (Adansonia digitata L.) (Figure 2D), the kapok tree (Ceiba pentandra (L.) Gaertn.), the locust bean tree and the Arabic gum tree (Acacia nilotica (L.) Delile).

From the late 1700s and early 1800s, most travel accounts (e.g., [13-16]) tend to narrow their focus to descriptions of economic potential of certain locally cultivated crops such as rice and peanuts, rather than discuss the region's flora, as a result of the gradual shift to legitimate commerce in western Africa (see for details $[17,18]$ ). Reports by Portuguese officials following the construction of the fort at Bissau and on the earliest European agricultural settlement on the Island of Bolama contained the first proposals for the cultivation of subsistence and trade crops $[13,19]$. The short-lived British settlement on Bolama Island documented by Beaver [13] included detailed descriptions of low-and upland rice, yams, and cassava (Manihot esculenta Crantz) being grown in coastal regions, as well as the presence of 
wild cotton (Gossypium spp.), sugar-cane (Saccharum officinarum L.), and indigo. An early reference was also made to groundnuts, but descriptions suggested that it probably referred to the bambara groundnut (Vigna subterranea (L.) Verdc.), a native herb common to the Bijagós Islands [16].
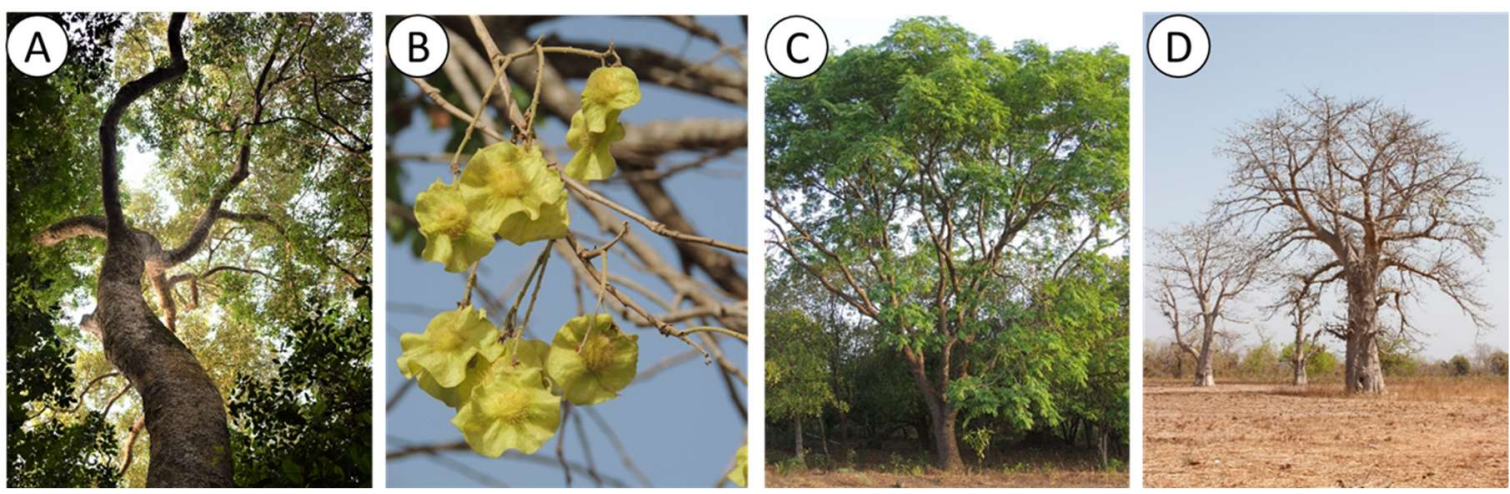

Figure 2. Plants of the Guinea-Bissau's flora reported in the early reports. (A) Guinea plum (Parinari excelsa Sabine) reported by Valentim Fernandes 1506-1507; (B) African rosewood (Pterocarpus erinaceus Poir.); (C) locust bean tree (Parkia biglobosa (Jacq.) R.Br. ex G.Don), mentioned by André Álvares $\mathrm{d}$ 'Almada in 1841; and (D) the emblematic baobab tree-Adansonia digitata L.- referred during the 17th century, in travel accounts provided among others by Francisco de Lemos Coelho. The generic name honoring Michel Adanson. (Photos by L. Catarino).

\subsection{Botanical Collections \& First Explorations}

\subsubsection{First Collections: The Role of the French Naturalists}

As stated above most of the early records on the Guinea-Bissau's flora focused on local subsistence agriculture and uses of native flora. The mid-18th century, when French expeditions to West African Region began to provide more detailed information on the local plants, marked the beginning of incipient floristic studies. These records and collections would generally focus on insular locations, such as the Bijagós Islands, off the Guinea Coast. The botanical exploration of the Canaries had already begun in the late 17th century with the visit by Cunningham (ca. 1665-1709), a Scottish naturalist who would produce the first herbarium collection, now kept in the Sloane Herbarium of the Natural Museum in London [20]. The Cabo Verde Islands would also attract naturalists such as Robertson, Staunton and Feijó, who recorded elements of the islands' flora and gathered botanical specimens during the 18th century [10].

The earliest botanical collections reported in the area of the Senegambia under French influence was carried out in the mid-18th century by Michel Adanson (1727-1806), who would become a distinguished French naturalist. In December 1748, Adanson left Paris to explore Senegal and the surrounding areas where he spent five years as an employee with the Compagnie des Indes, a Royal French trading company [21]. In February 1754, he returned with a large collection of plants, animals, and minerals, including over 5000 specimens of plants. Many were collected in West Africa, some of which became part of the French royal collection under the supervision of the naturalist Georges Buffon (1707-1788). Some of these specimens are housed in Paris in the herbarium of the Muséum Nationale d'Histoire Naturelle (P), while the bulk of the other specimens were incorporated in a personal collection [21]. Nevertheless, his major contribution to the natural sciences and botanical classification would only be recognized from the 1960s [21].

During this expedition, Adanson studied the natural history of St Louis (northern Senegal) and its surroundings, and made several journeys, including trips to Gorée Island (near Dakar), the town of Podor (northern Senegal), and the Gambia River. While still living in Senegal, he sent shipments of several hundred plants to Bernard de Jussieu, which were studied by Antoine Laurent de Jussieu (1748-1836), Adanson's mentor and Jussieu's brother, for his Genera Plantarum [22] and by many 
botanists thereafter. Only the first volume of the Histoire Naturelle du Sénégal was published by Adanson [23]. It contained an account of his travels, followed by a description of shells, but few references to plants, given that he intended to reserve his botanical discoveries for future volumes. Despite Adanson's significant contribution to knowledge of West African flora, and of Senegal in particular, there is no evidence that Adanson actually visited or collected plants within the limits of Guinea-Bissau. Nevertheless, he was knowledgeable about botanical explorations in West Africa and did obtain information on the flora of the region by means of third parties; i.e., French botanists visiting West Africa (pers. communication Charles Becker).

During the 19th century other French botanists followed Adanson's footsteps and visited West Africa, namely George Samuel Perrottet (1790-1870), a Swiss-born French botanist who joined several French expeditions to the Indian Ocean, Asia, and Latin America. From 1824 to 1829, Perrottet explored the Senegambian area, where he acted as general manager for the French Royal Trading Company [24]. An avid collector, prior to returning to France in 1829, he visited the Island of Gorée and apparently also collected in the Cabo Verde archipelago. François Mathias René Leprieur (1799-1870), a French naval pharmacist and naturalist, also collected plant specimens in Senegambia together with Perrottet from 1824 to 1829. Upon his return to France in 1829, Leprieur started to write a botanical inventory based on his observations and collections in this region, which was completed by Perrottet, Jean Baptiste Antoine Guillemin (1796-1842), and Achille Richard (1794-1852), both botanists and medical doctors. It was eventually published as Florae Senegambiae Tentamen [25] with illustrations by Joseph Decaisne (1807-1882). According to Keay [26], Perrottet and Leprieur's plant collections from Senegambia are mainly housed in the herbaria of the Berlin Botanical Garden (B, Germany) and at the Natural History Museum (BM, United Kingdom). Leprieur also collected with his countryman Jean-Pierre Heudelot (1802-1837), a French botanist and plant collector, who was appointed director of the Habitation Royale (royal plantations) in the town of Richard-Tol (northern Senegal) in the 1820s where crops such as tobacco, coffee, sugar cane, cotton, and indigo were planted.

Heudelot collected species in the Bijagós archipelago and in Gambia between 1836 and 1837. His specimens are deposited in several herbaria including Harvard University's herbarium. Although, the above-mentioned naturalists carried out important prospections and collections of plant species in West Africa and above all in Senegambia, it is not immediately evident that these collections actually targeted the current political boundaries of Guinea-Bissau.

One of the earliest botanical collections from Guinea-Bissau was assembled in the mid-19th century by Desiré Édélestan Stanislas Aimé Jardin (1822-1896). Inspector General of the French Navy, Jardin collected plant species from the Americas, the Pacific, Europe, and Africa, including different West African regions. Between 1845 and 1848, he visited Gabon, Guinea, Senegal, as well as the Portuguese Senegambia, currently Guinea-Bissau [27]. The specimens are deposited in several herbaria, namely in the Musée d'Histoire Naturelle de Nantes (NTM) and also in the Herbaria of the Université de Caen $(\mathrm{CN})$, later transferred to P Herbarium.

With regard to Guinea-Bissau, Jardin [27] appears to have been the first naturalist to associate scientific names to plants collected in the Bijagós Islands and in the coastal region south of this archipelago (see Figure 1A,C; Supplementary Table S1). He recognized that the islands had so far rarely been explored and that many species collected there appeared to be unknown [27]. Several species, including Adansonia digitata (Figure 2D), are referred as being collected on the 'île du Miel' (Meio Island), a southern islet of the archipelago, while he also described the Isle of Bandim (also called l'île Bourbon by the French, currently Ilhéu dos Pássaros) (see Figure 1A), then still densely covered with trees-above all $A$. digitata. The surrounding area was marked by extensive mangroves bordering the coastline as well as along the banks of the Geba River.

In his publications, Jardin mentions a total of 28 species for Guinea-Bissau [27,28] (Supplementary Table S1), for which we provide identifications, based on the actual knowledge of Guinea-Bissau flora and, in some cases, in the existing herbarium specimens. In fact, eight herbarium specimens are housed in P, corresponding to five of these species; i.e., Aspilia kotschyi (Sch.Bip. ex Hochst.) Oliv. and Vernonia 
colorata (Willd.) Drake subsp. colorata (both with two specimens), Cyperus esculentus L., Ctenium elegans Kunth (two specimens; one is presented in Figure S1), and Schwenckia americana L. Although, few data are provided in Jardin's publications, it seems that he visited the Bijagós Islands between August 1847 (the month he reported the flowering of A. digitata on the Isle of Bandim) and February 1848, which corresponds to the date of the last known collected specimen (Supplementary Table S1).

Moreover, the presence of cultivated and introduced species, such as Arachis hypogea L., Nicotiana tabacum L., and Saccharum officinarum L., provides evidence of the agricultural use of these islands at the time. The first cultivation of export crops had been initiated on the islands of Bolama and Galinhas after their settlement by Caboverdean, Guinean and Portuguese traders in the 1830s [17]. There is a notable prevalence of species from wet areas such as riparian forests, mangrove borders, river banks, wet grasslands or flooded rice fields, as well as the large number of herbaceous species.

Except for marine algae Caulerpa sertularioides (S.G.Gmelin) M.Howe, most of the species are vascular plants, including a fern (Platycerium stemaria (P. Beauv.) Desv.). Three specimens were referred as type specimens by Steudel in his publication Synopsis Plantarum Glumacearum [29]: P00568955, holotype of Cyperus bulamensis Steud. (named after Bolama, one of the Bijagós Islands); and P00439448 and P00439449, holotype and isotype, respectively, of Ctenium serpentinum Steud. (Figure S1; Table 1).

Table 1. Specimens collected in Guinea-Bissau designated as nomenclatural types.

\begin{tabular}{cl}
\hline Collector Name & \multicolumn{1}{c}{ Type Specimens } \\
\hline Desiré Édélestan S. Aimé Jardin & Holotype of Cyperus bulamensis Steud. (P) Holotype and isotype of Ctenium serpentinum Steud. (P) \\
\hline Paul Friedrich J. Moritz Pogge & Syntype of Loranthus constrictiflorus Engl. (Loranthaceae) Pogge 1322, 12-1880 (B) \\
\hline & Holotype of Anthericum immaculatum Hepper (Anthericaceae) Espírito-Santo 2922, 11 June 1951 (K) \\
& Holotype of Byrsanthus brownii Guillem. var. latifolius A.Fern. \& A.Diniz (Flacourtiaceae) Espírito-Santo 484, \\
& 1933 March 01 (COI). \\
& Holotype of Craterostigma guineense Hepper (Scrophulariaceae) Espírito-Santo 1424, 11 December 1942 (K). \\
& Holotype of Monochoria brevipetiolata Verdc. (Pontederiaceae) Espírito-Santo 2777, 18 September 1950 (K). \\
& Holotype of Hyphaene santoana Furtado (Palmae) Espírito-Santo 2425, 28 January 1948 (LISC). \\
& Holotype of Indigofera omissa J.B.Gillett var. trifoliolata J.B.Gillett (Fabaceae) Espírito-Santo 3530, 26 October \\
& 1955 (LISC). \\
& Holotype of Pandanus guineabissauensis Huynh (Pandanaceae) Espírito-Santo 2156, 1 August 1945(LISC). \\
& Holotype of Rotala tenella Hiern forma fluviatilis A. Fern. \& A. Diniz (Lythraceae), Espírito-Santo 2370A, \\
& 27 January 1947 (COI). \\
& Syntype of Tapinanthus pentagonia (DC.) Van Tiegh. var. guineensis S.Balle (Loranthaceae) Espírito-Santo 2505, \\
& 10 June 1949 and 2497, 9 June 1949 (COI). Hoaquim V. Espírito Santo \\
& Holotype of Trichilia emetica Vahl subsp. suberosa J.J. de Wilde (Meliaceae) Espírito-Santo 1808, \\
& 22 February1945 (LISC). \\
& Holotype of Indigofera spicata var. brevicarpa J.B.Gillett Espírito-Santo 3164, 19 June 1952 (K) \\
\hline Holotype of Dichrostachys cinerea (L.) Wight \& Arn. var. occidentalis Brenan \& Brummitt (Fabaceae) d'Orey \\
\hline \multirow{2}{*}{ José Sampaio de Albuquerque d'Orey } \\
\hline
\end{tabular}

\subsubsection{Naturalists from the Late 19th Century. Early Portuguese Expeditions}

Besides the important role of the botanical expeditions made by renowned French naturalists in West Africa and particularly in Senegambia, the first known Portuguese contribution to botanical study of Guinea-Bissau's flora was made by Manuel Rodrigues de Carvalho (1848-1909). In 1884, he collected some plant specimens on Bolama Island where the capital of the then autonomous region of Portuguese Guinea was established in 1879. Thereupon, he sent his collection to the Herbarium of the University of Coimbra (COI, Portugal) [30]. The district health officer Isaac Damasceno da Costa produced an inventory of medicinal species plants with their vernacular names in 1886, shedding light on a hitherto ignored subject [31]. A number of specimens were harvested in 1889 by João António Cardoso Júnior (1857-1937)—a pharmacist working in the health services of the Cabo Verde archipelago who published a list of medicinal plants [32].

In the late 1890s, the Portuguese military officer Henrique Augusto Dias de Carvalho (1843-1909) spent two years in the territory working for the Company of Trade and Exploration of Guinea, funded by foreign (French) capital [33]. The plant specimens he collected are currently housed in the COI Herbarium. His travel notes recorded in 1898-1900, provide insights into the native flora and crop species characterizing the region's landscape during the late 19th century [34]. His account and collections demonstrate a notable emphasis on species with commercial value such as the cashew 
nut tree (Anacardium occidentale L.) and latex producing species (i.e., Landolphia heudelotii A.DC., L. owariensis P. Beauv., Saba senegalensis (A.DC.) Pichon), cotton (Gossypium spp.), and sugar cane (Saccharum officinarum L.), as well as of baobab (Adansonia digitata: Figure 2D), kola (Cola nitida (Vent.) Schott \& Endl.), fig trees (Ficus spp.), and purging nut (Jatropha curcas L.). Other accounts such as that by the Portuguese agronomist Henrique de Arpoare and the naturalist Joaquim Machado da Fonseca as well as the German naturalist Max Julius Dinklage, recorded elements on the natural vegetation of the late 19th and early 20th centuries (Supplementary Table S2).

\subsection{The Colonial Era: Early 20th Century to 1974}

During the colonial period (1915-1974), that began after the occupation of Portuguese Guinea by military means, colonial policies transformed the territory into a single crop export economy, based upon the production of peanuts [35]; after independence a shift towards single crop cashew economy would occur from the mid-1980s onwards [36].

During the first decades of the 1900s, linked to the operative occupation of territory by the colonial authorities, biodiversity, indigenous human settlement, and agricultural practices were documented in greater detail [37,38]. Joaquim Machado da Fonseca was probably the first collector who worked in the interior of the territory; from 1910 to 1915, he collected plants in different areas such as Cacheu, Arame, Bissorã, Mansoa Farim, Bafatá, Buba, and Cacine (see Figure 1A). Following these botanical incursions, other naturalists were charged by the Portuguese government to carry out reconnaissance missions in order to map the economic potential of agriculture and forestry of the territory, while also collecting plant specimens. The most important collections were assembled by António Figueiredo Gomes e Sousa in 1927 and 1928, and a few years later the agronomist Manuel Martins Baptista who travelled the colony between 1932 and 1934. Gomes e Sousa published the first comprehensive study of the territory's flora and vegetation [39], providing detailed illustrations of several plant species (Figure 3: Adansonia digitata-3A; Parinari excels-3B; Pterocarpus erinaceus-3C).

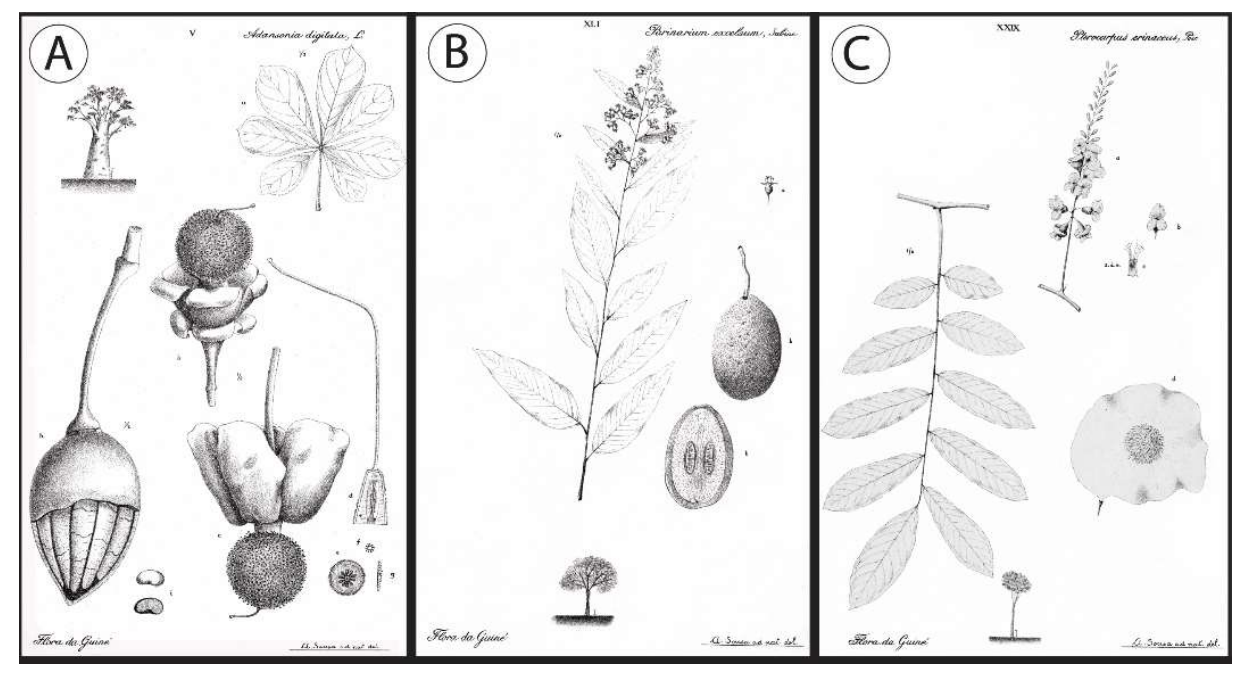

Figure 3. Illustrations of plant species published by Gomes e Sousa (1930) in the framework of the first comprehensive study of the Guinea-Bissau's flora and vegetation. (A) Baobab tree (Adansonia digitata L.); (B) Guinea plum (Parinari excelsa Sabine); (C) African rosewood (Pterocarpus erinaceus Poir.). Copyright, Universidade de Coimbra, Portugal.

Throughout the mid-20th century several scientific expeditions were undertaken by Portuguese researchers under the auspices of the Tropical Research Institute (IICT/University of Lisbon) (Figure 4). The principal botanist and collector whose collections had been shipped and deposited mainly in Portuguese herbaria (see details in Supplementary Table S2), is undoubtedly Joaquim Viegas da Graça Espírito Santo. Born in 1901 on the island of São Tomé (Gulf of Guinea), he worked for the 
colonial Agricultural and Forestry Services (1932-1972) and was killed towards the end of the colonial war (1963-1974). He brought together the largest collection of Guinea-Bissau flora, with about 5000 specimens, which are mainly housed in Portuguese (LISC from IICT/University of Lisbon, and COI) and British (BM and K) herbaria. He also published important studies with key data on vernacular names, uses and the ecology of several plant species from Portuguese Guinea [40-42]. Other plant collectors such as José Soares gathered about 400 specimens between 1943 and 1944, which are currently deposited in the LISC Herbarium in Lisbon. Another Portuguese botanist, Ester Pereira de Sousa, carried out extensive taxonomic studies on the LISC Herbarium collection from the mid-1940s to the early 1960s [43].

During the following decade, botanical exploration was expanded with the creation of the Brigade for Forestry Studies in Portuguese Guinea (Brigada de Estudos Florestais da Guiné Portuguesa) with experts from the Colonial Garden in Lisbon, currently the Tropical Botanical Garden (JBT-IICT/University of Lisbon). The Brigade, whose purpose was to "collect elements of study on the province's (Portuguese Guinea) forests", was headed by the agronomist José Sampaio d'Orey (1910-1980) [44]. Between 1953 and 1954, he was charged with a botanical mission to the colony, collecting about 3000 specimens, which are mainly housed in COI, K, LISC, and LISU Herbaria [45,46]. In 1956, the forestry engineer José Martins Santareno who formed part of the improvement program of the palm oil tree of the Brigade for Agronomic Studies of Portuguese Guinea (Brigada de Estudos Agronómicos), collected a few specimens that are currently kept in the LISC herbarium [47]. Noteworthy too are two botanical explorations carried out to gather data on the vegetation types with importance to the economic development of the territory. They were led by António R.F. Raimundo and J.A. Guerra between November 1960 and January 1961, and by Joaquim A. Pereira and Manuel F. Correia, between December 1961 and September 1962, resulting in a collection of about 4000 specimens, which are kept at the LISC Herbarium [48]. The data on the main botanical explorations in the region and the naturalists involved since the 18th century until the independence in 1974 are summarized in Supplementary Table S2.

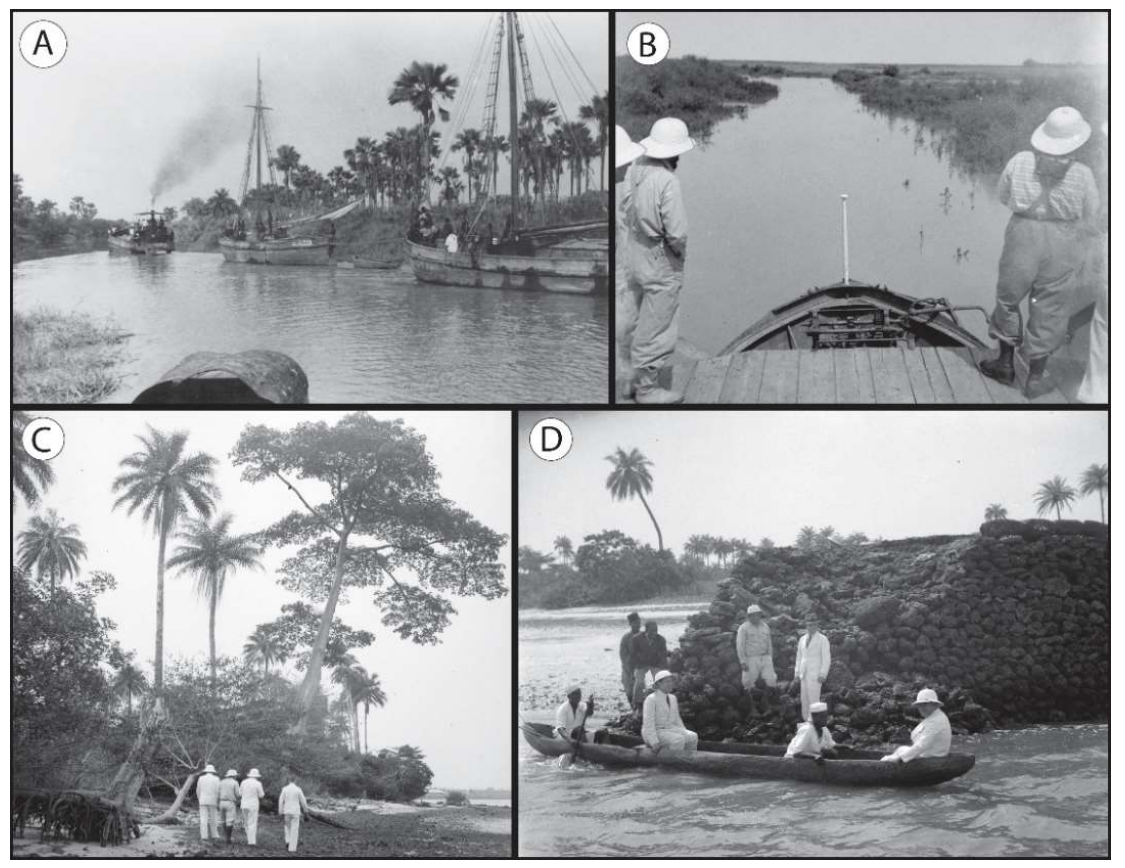

Figure 4. Scientific research expeditions to Guinea-Bissau undertaken by the Tropical Research Institute (IICT): (A) Geba River, near the village of Cuor. Photo: Fernando Frade, 1946; (B) Imperial river. Photo: Bernardo Coelho Gonçalves, 1945. Bijagós Islands: (C) Bubaque Island; (D) Canhabaque Island. Photos of Elmano Cunha e Costa 1935-1939. Copyright, Instituto de Investigação Científica Tropical (IICT/Universidade de Lisboa), Portugal. 
Furthermore, in 1956 and 1963, the first agricultural censuses were carried out mapping the entire country [49,50]. The Guinean Brigade of the Overseas Agronomical Studies Mission (Missão de Estudos Agronómicos do Ultramar, 1960-1983) was to produce a series of scientific reports, while erecting experimental agricultural stations and crop storage facilities in rural areas. During this period, several remarkable researchers from the University of Coimbra, including Abílio Fernandes (1906-1994), and Rosette Fernandes (1916-2005), published data on various taxonomic groups of Guinea-Bissau's flora [51-53]. These and other taxonomic studies, mainly published between the late 1940s and 1960s illustrate the growing body of botanical knowledge in the colony encompassing subsistence as well as export crops. They formed an integral part of state sponsored investment in the economic and scientific exploration of the colony (see Figure 4). The outbreak of armed conflict in 1963 as Portuguese rule was challenged by nationalist liberation movements, would increasingly limit the scope of scientific prospection during the 1960s and early 1970s.

\section{Current Knowledge of Guinea-Bissau's Plant Diversity}

Our study underlies that until the mid-1800s, botanical explorations undertaken in the Guinea-Bissau region were rather incipient, contrasting with more extensive scientific expeditions conducted in other West African countries, namely by Adanson (1727-1806) and other French naturalists on areas of French influence (e.g., Senegal). The earliest documented plant collections of the Guinea-Bissau region were gathered by the French botanist Jardin, in the Bijagós Islands between 1845 and 1848. The list of specimens constitute a landmark in this respect and it is published here for the first time (see Supplementary Table S1).

The signing of a treaty between France and Portugal in 1886, established the frontiers between French West Africa (Senegal and French Guinea) and Portuguese Guinea, and delineated a small Portuguese ruled enclave in Francophone Africa. The studies undertaken by the renowned French botanist, Auguste Chevalier (1873-1956) in French West Africa would mark the beginning of a revival of botanical explorations in the region [54]. Similar studies were also carried out by British botanists and large collections of specimens were assembled for West African flora in the 1920s and 1930s-including data from British, French, and Portuguese colonies $[55,56]$ mainly kept at the Royal Botanical Gardens in Kew.

The first attempts to make an inventory of Portuguese Guinea's flora were only carried out in the early 1930s, above all by Gomes e Sousa [39]. The herbarium collections were mainly assembled between 1945 and the 1960s as the scientific exploration of the territory gained momentum. Most of these collections are housed in Portuguese Herbaria (e.g., LISC and COI). In the early 1970s, d'Orey and Liberato initiated the publication of fascicles with detailed studies on the flora of Portuguese Guinea which continued after independence; i.e., on Guinea-Bissau Flora [44,57].

Armed conflict (1963-1974) would however gradually limit ongoing colonial research activities in the territory during the second half of the 1960s until its independence in 1974. As French colonies such as Senegal and the Republic of Guinea (see Figure 1A) became independent in 1958 and 1960 respectively, botanical research continued in the field and in herbaria, including the Herbarium and the Botanical Gardens in Dakar [58-60]. Following independence in 1974, Guinea-Bissau would experience a series of important political and economic changes. During the last two decades of the 20th century, botanical studies have been resumed by means of collaborative international projects involving local botanists and institutions as well as foreign, mainly Portuguese, researchers [61]. The botanical expeditions and the significant plant collections assembled over the last 200 years, recently served as baseline data for several country-wide studies, including a checklist of Guinea-Bissau flora [2] and an ethnobotanical study of the medicinal plants used by indigenous communities [3]. Despite these and other recent studies, in terms of botanical research Guinea-Bissau remains one of the least known countries in West Africa. 


\section{Conclusions}

The present study provides the first historical overview of the development of botanical knowledge on Guinea-Bissau from the 16th to the 20th centuries. Three principal plant recording periods were identified in this review, namely: (i) the early records of plants and reports on vegetation (late 15th to-17th centuries); (ii) the expeditions undertaken until the late 1800 s by mostly French but also Portuguese officials and naturalists, collecting data on Senegambia's natural environment, vegetation and human settlement; and (iii) the era of colonial rule from 1915 to 1974, during which both coastal and inland localities were explored, above all after 1945 with the advent of systematic scientific exploration.

From the earliest collections made in Guinea-Bissau territory to the present, the collection effort demonstrates a geographical and chronological pattern associated with the political changes in the region. While early efforts focused on the regions' main rivers but remained limited to the vicinity of trading posts, the first scientific expeditions targeted insular areas such as the Bijagós Islands, where some form of colonial control and settlement was established from the 1830s onwards. Gradually, the collection effort extended from the islands to coastal mainland areas from the late 19th century and the first decades of the 20th century as the colonial administration implanted itself in the territory. The advent of export crop cultivation (e.g., peanuts) in the late 1800s would have an important impact on the focus of botanical research [62]. The bulk of botanical collections was gathered between the 1930s and the 1950s as colonial scientific missions explored the littoral and the interior zone. After independence in 1974 most collections were assembled within the scope of R\&D projects, and particularly focused on the protected areas that are mainly located in insular (Área Protegida das Ilhas de Urok; Parque Nacional Marinho João Vieira e Poilão; and Parque Nacional das Ilhas de Orango) and coastal zones (Parque Natural das Lagoas de Cufada; Parque Nacional de Cantanhez: and Parque Natural dos Tarrafes de Cacheu) [1,61], which are still the best documented areas in Guinea-Bissau.

The knowledge of botanical research of the West African region is far from complete, and it is thus important to provide new insights into differential chronological patterns in terms of the gathering and study of scientific collections. Our study revealed that systematic knowledge of the plant diversity of Guinea-Bissau is very recent, and that the collecting efforts were only effectively increased from the 1930s onwards, as the first botanical collections were assembled for research. The work by Gomes e Sousa is highlighted here, for making the first inventory of local flora. A comparison can be made with the botanical history of adjacent territories. The Macaronesian Islands, such as the Canaries, Madeira, and Cabo Verde, are located at relatively close proximity to West Africa, but present a different, insular, tradition. It contrasts with patterns that our review has identified for the Senegambia and Guinea-Bissau regions. The first reports of pre-Linnean plant collectors already conducting extensive botanical surveys in these islands date back to the 17 th century (reviewed by $[10,20,63]$ ). Historical, geographical, and political reasons contributed to this situation. Macaronesia is located at closer proximity to Europe, and early colonization created opportunities for establishing strategic locations for shipping traveling from Europe to destinations in Africa and the Americas. Continental areas in West Africa, however, would only become the focus of botanical exploration as the interior, previously controlled by African societies, gradually became more accessible to European presence from the late 1800s. While falling under the same imperial power, policies with regard to scientific exploration were markedly different in the archipelago and continental territories such as Guinea-Bissau, owing to prevailing ecological and agro-economic conditions. Nevertheless, botanical research in the Cabo Verde Islands would tend to lag behind that carried out on the Island of Madeira and the Canary Islands, while the assembly of collections in Guinea-Bissau would also develop well after similar efforts in the surrounding French African colonies such as Senegal and the Republic of Guinea. Although botanical research in Guinea-Bissau was resumed in the 1990s as policies with regard to biodiversity and its protection gained ground, botanical surveys are needed to provide new data. The changes occurring in the country's ecosystem owing to the advancing Sahel region and the rapid growth of the cultivation 
of export crops (such as cashew) and the timber trade, increase the urgency for conducting further research on the conservation of the invaluable botanical resources of this small West African country.

Supplementary Materials: The following are available online at http:/ /www.mdpi.com/1424-2818/10/4/109/s1, Figure S1: Isotype of Ctenium serpentinum Steud "île de Miel", Jardin 124 B, P (Muséum National d'Histoire Naturelle, Paris (France), Collection: Vascular plants (P), Specimen P00439449), Supplementary Table S1: Édélestan Jardin: the first list of plants collected in Bijagós Islands (1845-48), Supplementary Table S2: Historical data on the principal botanical explorations of Guinea-Bissau flora (18th-early-20th centuries) with reference to collectors that are referred as has travelling through Senegambia.

Author Contributions: Conceptualization, M.M.R. and P.J.H.; Investigation and Resources, M.M.R., L.C. and P.J.H.; Analysis \& identification of botanical specimens, M.C.D, and L.C.; Writing-Original Draft Preparation, P.J.H. and M.M.R.; Writing-Review \& Editing, M.M.R, M.C.D., J.F-O., L.C. and. P.J.H.

Funding: This research was funded by the FCT-Portuguese Foundation for Science and Technology: CajOmics PTDC/AGR-PRO/5727/2014 also through Units funding UID/AGR/04129/2013 for Linking Landscape, Environment, Agriculture and Food (LEAF), and UID/BIA/00329/2013 for Centre for Ecology, Evolution and Environmental Changes (cE3c).

Acknowledgments: The authors are very grateful to the reviewers for their meticulous reading of the paper. We dedicate this paper to Cândida Liberato (IICT/University of Lisbon) in recognition of her contribution to the knowledge of the botanical explorations on the Portuguese-speaking African countries. We thank to Daniel Gann (FIU) for the preparation of the Figure 1A, and to Charles Becker (MNHN/Paris) for sending some details on explorations on West African region. Our gratitude to Arquivo Histórico Ultramarino (AHU, Lisbon) and to Museu Nacional de História Natural e da Ciência (MUHNAC/University of Lisbon - ULISBOA-IICT-ID21663, 22160) for the permissions to publish the figures of the Guinea-Bissau missions and to the Portuguese Research Infrastructure of Scientific Collections (PRISC). This is contribution number 358 of the Tropical Biology Program of Florida International University.

Conflicts of Interest: The authors declare no conflict of interest. The funders had no role in the design of the study; in the collection, analyses, or interpretation of data; in the writing of the manuscript, and in the decision to publish the results.

\section{References}

1. Catarino, L.; Havik, P.J.; Indjai, B.; Romeiras, M.M. Ecological data in support of an analysis of Guinea-Bissau's medicinal flora. Data Brief. 2016, 7, 1078-1097. [CrossRef] [PubMed]

2. Catarino, L.; Martins, E.S.; Pinto-Basto, M.F.; Diniz, M.A. An annotated checklist of the vascular flora of Guinea-Bissau (West Africa). Blumea 2008, 53, 1-222. [CrossRef]

3. Catarino, L.; Havik, P.J; Romeiras, M.M. Medicinal plants of Guinea-Bissau: Therapeutic applications, ethnic diversity and knowledge transfer. J. Ethnopharmacol. 2016, 183, 71-94. [CrossRef] [PubMed]

4. Almada, A.A. Tratado breve dos Rios de Guiné e do Cabo Verde; Editorial LIAM: Lisboa, Portugal, $1963 ;$ p. 154.

5. Cadamosto, L.de. Viagens de Luís de Cadamosto e de Pedro de Sintra; Academia Portuguesa de História: Lisboa, Portugal, 1948; p. 208.

6. Coelho, F.deL. Duas Descrições Seiscentistas da Guiné; Academia Portuguesa de História: Lisboa, Portugal, 1990; p. 283.

7. Donelha, A. Descrição da Serra Leoa e dos rios da Guiné de Cabo Verde; Junta de Investigações Científicas do Ultramar: Lisboa, Portugal, 1977; p. 471.

8. Fernandes, V. Descripção da Costa Ocidental de África do Senegal ao Cabo do Monte. In Monumenta Missionaria Africana: África Ocidental (1342-1499); Brásio, A., Ed.; Agência Geral do Ultramar: Lisboa, Portugal, 1958; pp. 672-745.

9. Romeiras, M.M.; Catarino, L.; Torrão, M.M.; Duarte, M.C. Diversity and origin of medicinal exotic flora in Cape Verde Islands. Plant Ecol. Evol. 2011, 144, 214-225. [CrossRef]

10. Romeiras, M.M.; Duarte, M.C.; Santos-Guerra, A.; Carine, M.A.; Francisco-Ortega, J. Botanical exploration of the Cape Verde islands: From the pre-Linnaean records and collections to the late 18th century accounts and expeditions. Taxon 2014, 63, 625-640. [CrossRef]

11. Francisco-Ortega, J.; Santos-Guerra, A.; Jarvis, C.E.; Carine, M.A.; Sequeira, M.; Maunder, M. Early British collectors and observers of the Macaronesian flora: From Sloane to Darwin. In Beyond Cladistics. The Branching of a Paradigm; Williams, D.M., Knapp, S., Eds.; University of California Press: Berkeley, CA, USA, 2010; pp. 125-144, ISBN 978-0-520-26772-5. 
12. Havik, P.J. Hybridising medicine: Illness, healing and the dynamics of reciprocal exchange on the Upper Guinea Coast (West Africa). Med Hist 60, 181-205. [CrossRef] [PubMed]

13. Beaver, P. African Memoranda: Relative to an Attempt to Establish a British Settlement on the Island of Bulama, on the Western Coast of Africa, in the Year 1792; C and R. Baldwin printer 1805: London, England, 1805; p. 500.

14. Bocandé, B. Sur la Guinée Portugaise ou Sénégambie Méridionale. Bulletin de la Societé de Geographie de Paris, 3e série 1849. T. II: 265-350; T. XII: 57-93.

15. Chelmicki, J.C.C.de; Varnhagen, F.A.de. Corografia Cabo Verdiana ou Descripção Geographico-Histórica da Provincia das Ilhas de Cabo Verde e Guiné; L.C. da Cunha: Lisboa, Portugal, 1841; Volume I, p. 304.

16. Lima, J.L.de. Ensaios Sobre a Estatística das Possessões Portuguesas na África Oriental e Occidental, na Ásia Occidental, na China e na Oceania; Imprensa Nacional: Lisboa, Portugal, 1844; Volumes I and II, pp. 100 and 127.

17. Bowman, J. Legitimate commerce and peanut production in Portuguese Guinea, 1840s-1880s. J. Afr. Hist. 1987, 28, 87-106. [CrossRef]

18. Brooks, G. Peanuts and colonialism: Consequences of the commercialization of peanuts in West Africa, 1830-1870. J. Afr. Hist. 1975, 16, 29-54. [CrossRef]

19. Andrade, B.A. Planta da Praça de Bissau e Suas Adjacentes; Academia Portuguesa da História: Lisbon, Portugal, 1990.

20. Santos-Guerra, A.; Jarvis, C.E.; Carine, M.A.; Maunder, M.; Francisco-Ortega, J. Late 17th century herbarium collections from the Canary Islands: The plants collected by James Cuninghame in La Palma. Taxon 2011, 60, 1734-1753.

21. Carteret, X. Michel Adanson in Senegal (1749-1754): A great naturalistic and anthropological journey of the Enlightenment. Rev. Hist. Sci. 2012, 65, 5-25. [CrossRef]

22. Jussieu, A.L.de. Genera Plantarum; Hérissant et Barrois: Paris, France, 1789.

23. Adanson, M. A voyage to Senegal, the isle of Goree, and the river Gambia; J. Nourse and W. Johnston: London, England, 1759; p. 33.

24. Raman, A. Georges Guerrard Samuel Perrottet, a forgotten Swiss-French plant collector, experimental botanist and biologist in India. Curr. Sci. India 2014, 107, 1607-1612.

25. Guillemin, J.A.; Perrottet, G.S.; Richard, A. Florae Senegambiae Tentamen; Treuttel et Wurtz: Paris, France, 1830-1833; p. 316.

26. Keay, R.W.J. Botanical collectors in West Africa prior to 1860. In Comptes Rendus de la IVe Réunion de l'Association Pour l'Étude Taxonomique de la Flore d'Áfrique Tropicale; Fernandes, A., Ed.; Junta de Investigações do Ultramar: Lisboa, Portugal, 1962; pp. 55-68.

27. Jardin, E. Herborisations sur la Côte Occidentale d'Afrique Pendant les Années 1845, 1846, 1847, 1848; P. Dupont: Paris, France, 1850-1851; p. 20.

28. Jardin, E. Énumération de Nouvelles Plantes Phanérogames et Cryptogames Découvertes Dans l'ancien et le Nouveau Continent; Imprimerie de Le Blanc-Hardel: Caen, France, 1875; p. 100.

29. Steudel, E.G. Synopsis Plantarum Glumacearum; 2 vols. J.B. Metzler: Stuttgartaiae, Germany, 1855; pp. 348, 475. Available online: https://archive.org/details/synopsisplantar00steugoog/page/n0 (accessed on 16 February 2018).

30. Exell, A.W.; Fernandes, A.; de Mendonça, F. Colectores botânicos da África Portuguesa. Bol Soc Broteriana, Sér. 2 1952, 26, 213-218.

31. Da Costa, D.I. Relatório do Serviço da Delegação da Junta de Saúde na villa de Bissau respectivo ao ano de 1884. Boletim Oficial da Guiné Portuguesa 1886, 2.

32. Cardoso Júnior, J.A. Subsidios Para a Materia Medica e Therapeutica das Possessões Ultramarinas Portuguezas; Typographia da Academia Real das Sciencias: Lisboa, Portugal, 1902; p. 326.

33. Havik, P.J. Na terra do novo Deus: Henrique Dias de Carvalho na Guiné. In Memórias de um Explorador: A Colecção Henrique Dias de Carvalho na Sociedade de Geografia de Lisboa; Cantinho, M., Ed.; Sociedade de Geografia de Lisboa: Lisboa, Portugal, 2012; pp. 271-280.

34. Dias de Carvalho, H. Guiné: Apontamentos Inéditos; Agência Geral das Colónias: Lisboa, Portugal, 1944; p. 254.

35. Havik, P.J. Guinea Bissau's rural economy and society: A reassessment of colonial and postcolonial dynamics. In Guinea Bissau: From Micro-State to 'Narco-State; Chabal, P., Green, T.O., Eds.; Hurst: London, UK, 2016; pp. 55-79. 
36. Monteiro, F.; Catarino, L.; Batista, D.; Indjai, B.; Duarte, M.C.; Romeiras, M.M. Cashew as a high agricultural commodity in West Africa: Insights towards sustainable production in Guinea-Bissau. Sustainability 2017, 9 , 1666. [CrossRef]

37. Fonseca, J.M. Relatório Sobre a Agricultura na Província da Guiné; Tipografia La Becarré: Lisboa, Portugal, 1915.

38. Vasconcellos, E.C. Guiné Portuguesa: Estudo Elementar de Geografia Física, Económica e Política; Tipografia da Cooperativa Militar: Lisboa, Portugal, 1917; p. 107.

39. Gomes e Sousa, A.F. Subsídios Para o Conhecimento da Flora da Guiné Portuguesa; Memórias da Sociedade Broteriana; Imprensa da Universidade: Coimbra, Portugal, 1930; p. 94.

40. Espírito Santo, J.V.G. Contribuição para o conhecimento fitogeográfico da Guiné Portuguesa. Boletim Cultural da Guiné Portuguesa 1949, 4, 95-129.

41. Espírito Santo, J. Plantas úteis da flora da Guiné Portuguesa. Boletim Cultural da Guiné Portuguesa 1953, 8, 61-68.

42. Espírito Santo, J. Nomes vernáculos de algumas plantas da Guiné Portuguesa. Estud. Ensaios Doc. Junta Invest. Ci. Ultramar 1963, 104, 1-123.

43. Sousa, E.P. Contribuições para o conhecimento da flora da Guiné Portuguesa. Estud. Ensaios Doc. Junta Invest. Ci. Ultramar 1960, 77, 1-101.

44. Liberato, M.C. Exploradores botânicos nos Países Africanos de Língua Oficial Portuguesa. Garcia de Orta. Sér. Bot. 1994, 12, 15-38.

45. Carvalho, J.A.T.; Nunes, F.J.S.F.P. Contribuição para o estudo do problema florestal da Guiné Portuguesa. Estud. Ensaios Doc. Junta Invest. Ci. Ultramar 1956, 30, 1-194.

46. Hepper, F.; Neate, F. Plant collectors in West Africa. Regnum Vegetabile 1971, 74, 1-96.

47. Silva, L. Trabalhos de base a cargo das Brigadas de Estudos Agronómicos do Ultramar para o segundo plano de fomento. Agros 1959, 4, 253-254.

48. Duarte, M.C.; Catarino, L.; Moreira, I. Notícia sobre os estudos fitossociológicos em África. Quercetea 1999, 1, 7-30.

49. Cabral, A. A agricultura na Guiné: Algumas notas sobre as suas características e problemas fundamentais. Agros 1959, 43, 335-350.

50. CIAU. Recenseamento agrícola da Guiné, 1960-61; Comissão para os Inquéritos Agrícolas do Ultramar: Lisboa, Portugal, 1963; p. 54.

51. Fernandes, R. Estudos nas Anacardiaceae africanas. III. Contribuição para o conhecimento das Anacardiaceae da Guiné Portuguesa. Garcia de Orta 1966, 14, 381-390.

52. Fernandes, A.; Diniz, M.A. Uma nova espécie do género Nesaea Commers. Boletim da Sociedade Broteriana, Sér. 2 1954, 28, 215-217.

53. Fernandes, A.; Fernandes, R. Contribuição para o conhecimento das Melastomataceae da Guiné Portuguesa. Garcia de Orta 1954, 2, 273-285.

54. Chevalier, A. La flore vivante de l'Afrique Occidentale Française Vol 1; Muséum National d'Histoire Naturelle: Paris, France, 1938; p. 360.

55. Hutchinson, J.; Dalziel, J.M. Flora of West Tropical Africa. Vol. I; Crown Agents for the Colonies: London, England, 1926; p. 525.

56. Hutchinson, J.; Dalziel, J.M. Flora of West Tropical Africa. Vol. II; Crown Agents for the Colonies: London, England, 1936; p. 651.

57. d'Orey, J.; Liberato, M.C. Flora da Guiné Portuguesa, Papilionaceae; Jardim-Museu Agrícola do Ultramar: Lisboa, Portugal, 1971; p. 172.

58. Adam, J.-G. Noms vernaculaires de plantes du Sénégal. Journal d'Agriculture et de Botanique Appliquée 1970, 17, 243-294. [CrossRef]

59. Berhaut, J. Flore du Sénégal; Claireafrique: Dakar, Senegal, 1967; p. 485.

60. Kerharo, J. Révue des plantes medicinales et toxiques du Sénégal. Plantes Medicinales et Phytotherapie 1968, 2, 108-146.

61. Indjai, B.; Catarino, L.; Mourão, D. Mezinhos de Orango-Plantas medicinais e pessoas da ilha da Rainha Pampa; IBAP: Bissau, Guinea-Bissau, 2010; p. 175. 
62. Havik, P.; Monteiro, F.; Catarino, S.; Correia, A.; Catarino, L.; Romeiras, M.M. Agro-Economic Transitions in Guinea-Bissau (West Africa): Historical Trends and Current Insights. Sustainability 2018, 10, 3408. [CrossRef]

63. Sequeira, M.M.; Santos-Guerra, A.; Jarvis, C.E.; Oberli, A.; Carine, M.A.; Maunder, M.; Francisco-Ortega, J. The Madeiran plants collected by Sir Hans Sloane in 1687, and his descriptions. Taxon 2010, 59, 598-612. 